\title{
COX-2 inhibitors and the heart: are all coxibs the same?
}

\author{
P Sooriakumaran
}

Postgrad Med J 2006;82:242-245. doi: 10.1136/pgmi.2005.042234

The selective COX-2 inhibitors (coxibs) were originally developed to minimise the adverse effects of conventional non-steroidal anti-inflammatory drugs (NSAIDs) while maintaining the same analgesic and anti-inflammatory properties. Many large studies confirmed the improved gastric side effect profile of coxibs compared with nonselective NSAIDs; however, reports of increased cardiovascular morbidity and mortality followed, and the manufacturer Merck was forced to withdraw rofecoxib (Vioxx) from the market. Other coxibs have also either perished or had restrictions placed on their use. However, there seem to be significant differences between coxibs regarding their cardiovascular profiles, and the evidence for a class effect is dubious. In this paper, the current body of knowledge regarding the cardiovascular toxicities of coxibs is reviewed. The take home message for prescribing NSAIDs and those coxibs still on the market seems to be one of caution rather than contraindication, except in patients with significant cardiovascular risk factors.

Correspondence to: Mr P Sooriakumaran Postgraduate Medical School, University of Surrey, Manor Park, Daphne Jackson Road, Guildford, Surrey, UK; p.s@doctors.org.uk

Submitted 7 October 2005 Accepted 5 January 2006
$\mathrm{T}$ here is a conflicting body of data in the literature regarding the association between the use of selective cyclo-oxygenase-2 inhibitors (the so called coxibs) and adverse cardiac events. ${ }^{1}$ Coxibs were first introduced as alternative analgesics to conventional nonsteroidal anti-inflammatory drugs (NSAIDs). The approval of rofecoxib (Vioxx) and celecoxib (Celebrex) by the Food and Drug Administration (FDA) in the USA came in 1999 with their subsequent market release. As the coxibs are specific for the COX-2 isoform of the cyclooxygenase enzyme it was believed that they would cause fewer side effects than non-selective NSAIDs. Numerous large scale studies confirmed that coxibs did cause fewer gastric side effects Institute for Health and Clinical Excellence (NICE) in the UK recommended that all patients at risk of gastric side effects, including all patients over the age of 65 , who needed a NSAID should receive a coxib. ${ }^{7}$ Before its FDA approval, 5435 patients had taken rofecoxib, generally as part of small, short term trials; however, even at that time the medical officer of the FDA observed "that in six-week studies, thromboembolic events are more frequent in patients receiving rofecoxib ( $12(0.67 \%)$ of 1780$)$ than placebo ( $1(0.24 \%)$ of 412$)^{\prime \prime} .{ }^{8}$ This finding did not stop the subsequent granting of approval from the FDA. than non-selective NSAIDs, ${ }^{2-6}$ and the National
The Vioxx gastrointestinal outcomes research (VIGOR) trial ${ }^{2}$ was a large clinical trial that randomised patients with rheumatoid arthritis to rofecoxib $50 \mathrm{mg} /$ day or naproxen $1000 \mathrm{mg}$ /day. The trial found a twofold reduction in gastrointestinal events in the rofecoxib arm, but also showed a fivefold increase in the incidence of acute myocardial infarction in the rofecoxib arm when compared with the naproxen $\mathrm{arm}^{2}{ }^{2}$ This resulted in a longer projected life expectancy for the average rheumatoid arthritis patient taking naproxen compared with the patient taking rofecoxib. ${ }^{9}$ It is unclear at present whether the gastrointestinal side effect profile with coxibs is superior to a conventional NSAID combined with a proton pump inhibitor, ${ }^{10}$ and indeed even whether the analgesic effects of coxibs are superior to NSAIDs, ${ }^{11}$ further questioning the rationale for their use. Because there was no placebo arm in the VIGOR trial these findings could suggest either an adverse cardiac effect of rofecoxib or a previously unrecognised protective cardiac effect of naproxen.

It has been proposed that coxibs may adversely influence the prostacyclin (antithrombotic): thromboxane (prothrombotic) ratio in the vascular wall. Coxibs may inhibit the production of prostacyclin (antithrombotic) and leave thromboxane (prothrombotic) generation unaffected (as there are no COX-2 receptors in platelets), thus promoting platelet aggregation and atherosclerosis. ${ }^{12-14}$ Furthermore, inhibition of prostacyclin in the kidney could lead to sodium and water retention, causing hypertension. ${ }^{15}$ These biological actions might increase the risk of cardiovascular events, including myocardial infarction and stroke. ${ }^{14}$ The mechanism postulated for naproxen's possible cardioprotective effect is its inhibition of thromboxane with consequent platelet aggregation, ${ }^{12}$ and some authors have suggested combination therapy with non-selective NSAIDs to combat this. ${ }^{16}$

A recent nested case-control study by Graham et $a l^{17}$ examined a cohort of patients treated with an NSAID between I January 1999 and 31 December 2001, using data from the Kaiser Permanente. The Kaiser Permanente is a national integrated managed care organisation providing comprehensive health care to more than 6 million Californians, and thus a huge database that identified 2302029 person years of follow up. Of these, there were 8143 cases of serious coronary heart disease, each of which were riskset matched with four controls on age, sex, and health plan region. The multivariate odds ratio was 1.59 (95\% confidence interval 1.10 to 2.32 )

Abbreviations: NSAID, non-steroidal anti-inflammatory drug; COX-2, cyclo-oxygenase-2 
for all doses of rofecoxib, 1.47 (0.99 to 2.17) for $25 \mathrm{mg}$ or less daily, and 3.58 (1.27 to 10.11) for doses greater than $25 \mathrm{mg}$ daily, all compared with celecoxib. Celecoxib was not associated with any increased risk of cardiac events compared with remote (greater than two months ago) NSAID use (odds ratio $0.84,0.67$ to 1.04 ), while naproxen was found to confer a slightly increased risk (odds ratio 1.14, 1.00 to 1.30). Of further interest in this study is that the mean time to occurrence of a cardiac event was less than four months, suggesting that the cardiovascular risk of rofecoxib begins soon after the drug is started. The authors concluded that between 88000 and 140000 excess cases of serious coronary heart disease might have resulted from the use of rofecoxib rather than other NSAIDs or coxibs in the USA alone since its market launch in 1999.

Juni $e t$ a $l^{18}$ performed a standard and cumulative random effects meta-analysis of 18 randomised clinical trials identified from bibliographies and files of the FDA. They showed that by the end of 2001, those patients taking rofecoxib had a relative risk of myocardial infarction of 2.24 ( 1.24 to 4.02 ) compared with the control arm. Of particular note is the finding that this relative risk did not change with the control drug used, be it placebo, naproxen, or a non-naproxen NSAID. A UK study ${ }^{19}$ examining coxib and NSAID use in primary care found a significantly increased risk of myocardial infarction associated with current use of rofecoxib (odds ratio $1.32,1.09$ to 1.61 ) compared with no use in the previous three years; with current use of diclofenac (1.55, 1.39 to 1.72); and with current use of ibuprofen (1.24, 1.11 to 1.39). Increased risks were also associated with the other coxibs and non-selective NSAIDS compared with no use of NSAIDs or coxibs. However, this study was observational in design, and therefore may be subject to confounding, making its results less certain. ${ }^{19} 20$

The recently published adenomatous polyp prevention on Vioxx (APPROVe) trial ${ }^{21}$ examined the effects of rofecoxib on the incidence of benign sporadic colonic adenomas (known precursors of colon cancer). The manufacturers of rofecoxib, Merck, were forced to withdraw Vioxx from the market after the premature halting of the study by the external safety review board because of the finding that the group assigned to rofecoxib had a fourfold increased risk of serious thromboembolic events (mainly acute myocardial infarction and cerebrovascular accident) compared with the placebo group. ${ }^{3}$ Vioxx had achieved the most impressive global sales growth for any drug in 2001 with worldwide sales topping \$US 2.5 billion in 2004. ${ }^{22}$ It is estimated that 80 million people worldwide had taken Vioxx before its withdrawal. ${ }^{22}$ There is currently much litigation against Merck as a result of its aggressive marketing programme despite earlier safety warnings about the drug. ${ }^{3}$

As well as confirming an adverse risk cardiovascular profile for rofecoxib, the above studies do suggest that celecoxib is safer. Hudson et $a^{23}$ undertook a retrospective cohort study that included more than 2000 patients aged over 65 who were prescribed celecoxib, rofecoxib, or a non-selective NSAID at their index admission for congestive cardiac failure. They found that the combined risk of death and recurrent congestive cardiac failure was higher in patients prescribed rofecoxib or NSAIDs than in those prescribed celecoxib (hazard ratios 1.27 and 1.26 respectively). The celecoxib long term arthritis safety study (CLASS) ${ }^{24}$ was published in 2000 and compared celecoxib with either ibuprofen or diclofenac in patients with osteoarthritis or rheumatoid arthritis, and found no difference in the rates of myocardial infarction. However, CLASS also found no difference in adverse gastrointestinal events between the groups and, therefore, this study provides clinical evidence that celecoxib is less COX-2 selective than rofecoxib. ${ }^{24}{ }^{25}$ A 10 -fold reduction on COX-2 specificity for celecoxib compared with rofecoxib has also been found using whole cell assays. ${ }^{26}$

By the time of the withdrawal of rofecoxib, many second generation coxibs with improved COX-2 selectivity had been released on the market. These include valdecoxib, parecoxib, etoricoxib, and lumiracoxib. ${ }^{27}$ The therapeutic arthritis research and gastrointestinal event trial $(\text { TARGET) })^{28}$ found a hazard ratio of 1.77 (95\% CI 0.82 to 3.84) for myocardial infarctions in patients assigned lumiracoxib compared with naproxen. A recent randomised trial that compared valdecoxib (and its intravenous prodrug, parecoxib) with placebo for pain relief in patients undergoing coronary artery bypass surgery found an increased incidence of myocardial infarction and cerebrovascular accident at 30 days after just 10 days in the valdecoxib arm. ${ }^{29-31}$

Further ongoing trials looking at the newer coxibs as well as the older agents are awaited, but unfortunately they are mostly being performed in patients with rheumatoid arthritis as in CLASS and TARGET. It is known that rheumatoid arthritis itself is a risk factor for cardiac disease, probably because of a chronic heightening of circulating cytokine concentrations as well as $\mathrm{C}$ reactive protein and other proatherogenic inflammatory markers, with activation of leucocytes in both processes. ${ }^{32}{ }^{33}$ This is also thought to be the case for other chronic inflammatory conditions that typically require long term analgesia. ${ }^{34}$ Furthermore, this patient population tends to be elderly, and the risk of adverse drug events may not be comparable to a younger population. ${ }^{75}$ Hence, these studies will not answer the question of the risk: benefit ratio of short term use of these drugs in patients at little or no risk for adverse cardiac events. This is a crucial issue in discovering if the coxibs are safe in a chemopreventive role.

In contrast with the above studies suggesting that safety concerns regarding coxibs do not extend to celecoxib, the adenoma prevention with celecoxib (APC) trial $^{36}$ was suspended by the US National Cancer Institute when it was found that patients taking $400 \mathrm{mg}$ and $800 \mathrm{mg}$ daily celecoxib had a 2.5 -fold and 3.4-fold increase respectively in their risk of experiencing a major cardiovascular event compared with patients on placebo. A further randomised study of celecoxib in patients with Alzheimer's disease also showed unfavourable cardiovascular outcomes in the drug $\operatorname{arm}^{37}$

All of the above studies that have been published are summarised in table 1, listed in the order they have been discussed in the text.

\section{CONCLUSIONS}

The Medicines Healthcare products Regulatory Agency (MHRA), the European Medicines Agency (EMEA), and the Committee on Safety of Medicines (CSM) have all formulated guidelines on the prescribing of coxibs. The CSM have sent their guidelines to all UK doctors ${ }^{38}{ }^{39}$ (similar guidelines are issued by the EMEA):

- A contraindication is introduced for all COX-2 inhibitors in patients with ischaemic heart disease or stroke

- A warning is introduced for prescribers to exercise caution when prescribing COX-2 inhibitors for patients with risk factors for heart disease, such as hypertension, hyperlipidaemia, diabetes, and smoking, as well as for patients with peripheral arterial disease

The MHRA have added that "patients treated with any COX-2 inhibitor who have established ischaemic heart disease or cerebrovascular disease should be switched to 
Table 1 The major studies of coxibs and cardiovascular morbidity

\begin{tabular}{|c|c|c|c|c|}
\hline Study & $N=$ & Indication & Study design & Adverse cardiovascular events \\
\hline VIGOR $(2000)^{2}$ & 8076 & Rheumatoid arthritis & $\begin{array}{l}\text { Double blinded RCT (rofecoxib } \\
\text { compared with naproxen) }\end{array}$ & $\begin{array}{l}\mathrm{RR} \text { of } \mathrm{Ml} \text { in naproxen group was } 0.2 ; \\
\text { overall mortality and death from } \\
\text { cardiovascular causes similar }\end{array}$ \\
\hline $\begin{array}{l}\text { Graham et al } \\
(2005)^{17}\end{array}$ & $\begin{array}{l}\text { All patients aged 18-84 } \\
\text { treated with an NSAID } \\
\text { over a three year period } \\
\text { from a } 6 \text { million population } \\
\text { database ( } 2302029 \\
\text { person years) }\end{array}$ & Various - no strict criteria & $\begin{array}{l}\text { Nested case-control study of } \\
\text { cardiac events }\end{array}$ & $\begin{array}{l}\text { Compared with celecoxib RR for } \\
\text { rofecoxib was } 1.59 \text {. For naproxen } \\
\text { compared with remote NSAID use the } \\
\text { adjusted OR was } 1.14\end{array}$ \\
\hline Juni et al $(2004)^{18}$ & 21432 & $\begin{array}{l}\text { All bibliographic databases } \\
\text { and files of the FDA that } \\
\text { compared rofecoxib with other } \\
\text { NSAIDs or placebo, and trials } \\
\text { of cardiovascular risk and } \\
\text { naproxen }\end{array}$ & $\begin{array}{l}\text { Meta-analysis of } 18 \text { RCTs and } \\
11 \text { observational studies }\end{array}$ & $\begin{array}{l}\text { RR of MI for rofecoxib compared with } \\
\text { placebo, naproxen, or other NSAIDs } \\
\text { was } 2.24\end{array}$ \\
\hline $\begin{array}{l}\text { Hippisley-Cox and } \\
\text { Coupland }(2005)^{19}\end{array}$ & $\begin{array}{l}9218 \text { cases and } 86349 \\
\text { matched controls }\end{array}$ & $\begin{array}{l}\text { Primary care patients taking } \\
\text { coxibs and NSAIDs over a } \\
\text { five year period }\end{array}$ & $\begin{array}{l}\text { Nested case-control study using } \\
\text { QRESEARCH database (of } 367 \\
\text { UK GP surgeries) }\end{array}$ & $\begin{array}{l}\text { Adjusted OR compared to no use of } \\
\text { NSAID in past three years for rofecoxib } \\
\text { was } 1.32 \text {, for diclofenac was } 1.55 \text {, and } \\
\text { for ibuprofen was } 1.24 \text {. Increased risks } \\
\text { were also found for other coxibs and } \\
\text { NSAIDs albeit less dramatic. }\end{array}$ \\
\hline $\begin{array}{l}\text { Bresalier et al } \\
(2005) \\
(\text { APPROVe) }\end{array}$ & $\begin{array}{l}1287 \text { cases and } 1299 \\
\text { controls }\end{array}$ & History of colorectal adenomas & $\begin{array}{l}\text { Double blinded RCT (rofecoxib } \\
\text { compared with placebo) }\end{array}$ & $\begin{array}{l}\text { RR of confirmed thrombotic event (for } \\
\text { example, MI, CVA) for rofecoxib was } \\
1.92 \text { compared with placebo }\end{array}$ \\
\hline $\begin{array}{l}\text { Hudson et al } \\
(2005)^{23}\end{array}$ & 2256 & $\begin{array}{l}\text { Patients aged } \geqslant 66 \text { prescribed } \\
\text { celecoxib, rofecoxib, or a } \\
\text { NSAID after index admission } \\
\text { for CCF over a two year } \\
\text { period }\end{array}$ & $\begin{array}{l}\text { Population based retrospective } \\
\text { cohort study of hospital discharge } \\
\text { summary and prescription drug } \\
\text { databases }\end{array}$ & $\begin{array}{l}\text { Hazard ratio for death and recurrent } \\
\text { CCF combined was } 1.26 \text { for patients } \\
\text { prescribed NSAIDs or rofecoxib } \\
\text { compared with celecoxib }\end{array}$ \\
\hline $\begin{array}{l}\text { Silverstein et al } \\
(2000)(C L A S S)^{24}\end{array}$ & 8059 & $\begin{array}{l}\text { Patients aged } \geqslant 18 \text { with } \\
\text { osteoarthritis or rheumatoid } \\
\text { arthritis }\end{array}$ & $\begin{array}{l}\text { Double blinded RCT (celecoxib } \\
\text { compared with ibuprofen or } \\
\text { diclofenac) }\end{array}$ & $\begin{array}{l}\text { No difference in cardiovascular events } \\
\text { between celecoxib and NSAIDs }\end{array}$ \\
\hline $\begin{array}{l}\text { Farkouh et al } \\
(2004) \\
(\text { TARGET) })^{28}\end{array}$ & 18325 & $\begin{array}{l}\text { Patients aged } \geqslant 50 \text { with } \\
\text { osteoarthritis }\end{array}$ & $\begin{array}{l}\text { Double blinded RCT (lumiracoxib } \\
\text { compared with naproxen or } \\
\text { ibuprofen) }\end{array}$ & $\begin{array}{l}\text { Harzard ratio for MI for lumiracoxib } \\
\text { compared with naproxen was } 1.77 \\
\text { (non-significant) and for lumiracoxib } \\
\text { compared with ibuprofen was } 0.75 \\
\text { (non-significant) }\end{array}$ \\
\hline $\begin{array}{l}\text { Nussmeier et al } \\
(2005)^{31}\end{array}$ & 1671 & $\begin{array}{l}\text { Patients with postoperative } \\
\text { pain after } C A B G\end{array}$ & $\begin{array}{l}\text { Double blinded RCT (parecoxib } \\
\text { plus valdecoxib compared with } \\
\text { placebo plus valdecoxib } \\
\text { compared with placebo alone) }\end{array}$ & $\begin{array}{l}\text { RR for cardiovascular events (for } \\
\text { example, MI, CVA, PE, cardiac arrest) } \\
\text { for parecoxib plus valdecoxib compared } \\
\text { with placebo was } 3.7 \text { ) }\end{array}$ \\
\hline $\begin{array}{l}\text { Soloman et al } \\
(2005)(\text { APC })^{36}\end{array}$ & 2035 & History of colorectal adenomas & $\begin{array}{l}\text { Double blinded RCT over three } \\
\text { years (celecoxib low dose } \\
\text { compared } \\
\text { with celecoxib high dose } \\
\text { compared } \\
\text { with placebo) }\end{array}$ & $\begin{array}{l}\text { Hazard ratios for death from } \\
\text { cardiovascular causes (for example, MI, } \\
\text { CVA, CCF) compared with placebo for } \\
\text { low dose ( } 200 \text { mg twice daily) celecoxib } \\
\text { was } 2.3 \text { and for high dose ( } 400 \mathrm{mg} \\
\text { twice daily) celecoxib was } 3.4\end{array}$ \\
\hline
\end{tabular}

alternative (non-COX-2 selective) treatments as soon as is convenient". ${ }^{40}$ The FDA has also issued similar guidelines. ${ }^{41}$ Alternative drugs include conventional NSAIDs, paracetamol, and opioids.

There are published studies on cardiovascular adverse events with rofecoxib, celecoxib, and the newer agents parecoxib and valdecoxib. The evidence cited in this review shows that their cardiovascular safety profiles are not the same, and that celecoxib is probably the safest. This is most probably because of its lower specificity for the COX-2 enzyme. However, published evidence cited in this review also suggests that cardiovascular concerns extend to nonCOX-2-specific NSAIDs such as diclofenac and ibuprofen, and it remains to be elucidated whether celecoxib is safer than these conventional NSAIDs. It is also unclear whether the risk:benefit profile of celecoxib is superior to conventional NSAIDs plus gastric protection with a proton pump inhibitor, and further studies are needed to investigate this. At present it seems that celecoxib is the coxib of choice but that it does have adverse cardiac effects if used for prolonged periods, especially at high doses.

Funding: none.

Competing interests statement: none declared.

\section{REFERENCES}

1 Clark DW, Layłon D, Shakir SA. Do some inhibitors of COX-2 increase the risk of thromboembolic events? Linking pharmacology with pharmacoepidemiology. Drug Saf 2004;27:427-56.

2 Bombardier C, Laine L, Reicin A, et al. Comparison of upper gastrointestinal toxicity of rofecoxib and naproxen in patients with rheumatoid arthritis. VIGOR Study Group. N Engl J Med 2000;343:1520-8

3 Topol EJ. Failing the public health--rofecoxib, Merck, and the FDA. NEngl J Med 2004;351:1707-9.

4 Mamdani M, Rochon PA, Juurlink DN, et al. Observational study of upper gastrointestinal haemorrhage in elderly patients given selective cyclooxygenase-2 inhibitors or conventional non-steroidal anti-inflammatory drugs. BMJ 2002;325:624.

5 Jones R. Efficacy and safety of COX 2 inhibitors. BMJ 2002;325:607-8.

6 Deeks JJ, Smith LA, Bradley MD. Efficacy, tolerability, and upper gastrointestinal safety of celecoxib for treatment of osteoarthritis and rheumatoid arthritis: systematic review of randomised controlled trials. BMJ 2002;325:619.

7 Walsh K. Are COX-2 inhibitors really more likely to cause heart attacks and strokes than conventional NSAIDs? BMA News 2005;3:76.

8 Villalba M. FDA medical officer review of VIOX (rofecoxib), NDA 21-042 (capsules) and NDA 21-052 (oral solution). http://www.fda.gov/cder/foi/ nda/index.htm) (accessed 12 Feb 2005).

9 Choi HK, Seeger JD, Kuntz KM. Effects of rofecoxib and naproxen on life expectancy among patients with rheumatoid arthritis: a decision analysis. Am J Med 2004; 116:621-9.

10 Oviedo JA, Wolfe MM. Gastroprotection by coxibs: what do the celecoxib long-term arthritis safety study and the Vioxx gastrointestinal outcomes research trial tell us? Rheum Dis Clin North Am 2003;29:769-88. 
11 Meagher EA. Balancing gastroprotection and cardioprotection with selective cyclo-oxygenase-2 inhibitors: clinical implications. Drug Saf 2003;26:913-24.

12 Fitzgerald GA. Coxibs and cardiovascular disease. N Engl J Med 2004;351:1709-11.

13 McAdam BF, Catella-Lawson F, Mardini IA, et al. Systemic biosynthesis of prostacyclin by cyclooxygenase (COX)-2: the human pharmacology of a selective inhibitor of COX-2. Proc Natl Acad Sci U S A 1999;96:272-7.

14 Psaty BM, Furberg CD. COX-2 inhibitors--lessons in drug safety. N Engl J Med 2005;352:1133-5.

15 Krum H, Liew D, Aw J, et al. Cardiovascular effects of selective cyclooxygenase-2 inhibitors. Expert Rev Cardiovasc Ther 2004;2:265-70.

16 DeMaria AN, Weir MR. Coxibs--beyond the GI tract: renal and cardiovascular issues. J Pain Symptom Manage 2003;25:S41-9.

17 Graham DJ, Campen D, Hui R, et al. Risk of acute myocardial infarction and sudden cardiac death in patients treated with cyclo-oxygenase 2 selective and non-selective non-steroidal anti-inflammatory drugs: nested case-control study. Lancet 2005;365:475-81.

18 Juni P, Nartey L, Reichenbach S, et al. Risk of cardiovascular events and rofecoxib: cumulative meta-analysis. Lancet 2004;364:2021-9.

19 Hippisley-Cox J, Coupland C. Risk of myocardial infarction in patients taking cyclo-oxygenase-2 inhibitors or conventional non-steroidal anti-inflammatory drugs: population based nested case-control analysis. BMJ 2005;330:1366.

20 Buring JE, Glynn RJ, Hennekens CH. Calcium channel blockers and myocardial infarction. A hypothesis formulated but not yet tested. JAMA 1995;274:654-5

21 Bresalier RS, Sandler RS, Quan H, et al. Cardiovascular events associated with rofecoxib in a colorectal adenoma chemoprevention trial. N Engl J Med 2005;352:1092-102.

22 Maxwell SR, Webb DJ. COX-2 selective inhibitors--important lessons learned. Lancet 2005;365:449-51.

23 Hudson M, Richard H, Pilote L. Differences in outcomes of patients with congestive heart failure prescribed celecoxib, rofecoxib, or non-steroidal antiinflammatory drugs: population based study. BMJ 2005;330:1370.

24 Silverstein FE, Faich G, Goldstein JL, et al. Gastrointestinal toxicity with celecoxib vs nonsteroidal anti-inflammatory drugs for osteoarthritis and rheumatoid arthritis: the CLASS study: a randomized controlled trial. Celecoxib long-term arthritis safety study. JAMA 2000;284:1247-55.

25 Waskewich C, Blumenthal RD, Li H, et al. Celecoxib exhibits the greatest potency amongst cyclooxygenase (COX) inhibitors for growth inhibition of
COX-2-negative hematopoietic and epithelial cell lines. Cancer Res 2002;62:2029-33.

26 Wright JM. The double-edged sword of COX-2 selective NSAIDs. CMAJ 2002;167:1131-7.

27 Warner TD, Mitchell JA. Cyclooxygenases: new forms, new inhibitors, and lessons from the clinic. FASEB J 2004; 18:790-804.

28 Farkouh ME, Kirshner H, Harrington RA, et al. Comparison of lumiracoxib with naproxen and ibuprofen in the therapeutic arthritis research and gastrointestinal event trial (TARGET), cardiovascular outcomes: randomised controlled trial. Lancet 2004;364:675-84.

29 Drazen JM. COX-2 inhibitors--a lesson in unexpected problems. N Engl J Med 2005;352:1131-2.

30 Juni P, Reichenbach S, Egger M. COX 2 inhibitors, traditional NSAIDs, and the heart. BMJ 2005;330:1342-3.

31 Nussmeier NA, Whelton AA, Brown MT, et al. Complications of the COX-2 inhibitors parecoxib and valdecoxib after cardiac surgery. N Engl J Med 2005;352:1081-91.

32 Goodson NJ, Wiles NJ, Lunt M, et al. Mortality in early inflammatory polyarthritis: cardiovascular mortality is increased in seropositive patients. Arthritis Rheum 2002;46:2010-19.

33 del Rincon ID, Williams K, Stern MP, et al. High incidence of cardiovascular events in a rheumatoid arthritis cohort not explained by traditional cardiac risk factors. Arthritis Rheum 2001;44:2737-45.

34 Scott DG, Watts RA. Increased risk of cardiovascular events with coxibs and NSAIDs. Lancet 2005;365:1537.

35 Savage R. Cyclo-oxygenase-2 inhibitors: when should they be used in the elderly? Drugs Aging 2005;22:185-200.

36 Solomon SD, McMurray JJ, Pfeffer MA, et al. Cardiovascular risk associated with celecoxib in a clinical trial for colorectal adenoma prevention. $N$ Engl J Med 2005;352:1071-80.

37 Pfizer. A double-blind randomized pacebo-controlled comparative study of celecoxib (SC-58635) for the inhibition of progression of Alzheimer's disease, protocol IQ5-97-02-001. http://www.clinicalstudyresults.rg/documents/ company-study_76_0.pdf) (accessed 12 Feb 2005)..

38 CSM. http://www.mca.gov.uk/aboutagency/regframework/csm/ csmhome.htm.

39 EMEA. http://www.emea.eu.int.

40 MHRA. http://www.mhra.gov.uk.

41 FDA. http://www.fda.gov/cder/drug/infopage/COX2/default.htm. 